\title{
Alpha-glucosidases from Non-hematophagous Organisms Crystallize Heme in Vitro
}

\section{Lígia Souza Ferreira1, Gabriela Calegário1, Flávia Borges Mury², Marilvia Dansa de Alencar ${ }^{1}$}

${ }^{1}$ LQFPP, CBB, UENF, Campos dos Goytacazes, RJ, Brazil;

${ }^{2}$ NUPEM, Universidade Federal do Rio de Janeiro, Macaé, RJ, Brazil.

\begin{abstract}
Hemozoin (Hz), a heme crystal first known as a malaria pigment, reduces heme toxicity to hematophagous organisms such as protozoans, worms, and insects. The mechanism of $\mathrm{Hz}$ synthesis remains poorly understood, but studies on the blood-sucking insect Rhodnius prolixus indicate the involvement of an $\alpha$-glucosidase enzyme. The objective of this study was to test the hypothesis that $\alpha$-glucosidases from other organisms also have the ability to form $\mathrm{Hz}$ in vitro. This hypothesis was tested using protein extracts from non-hematophagous insects and non-insect organisms. Our results indicate that protein extracts from several sources have the potential to crystallize heme in vitro. This activity is likely associated with $\alpha$-glucosidases. Thus, these enzymes seem to have the secondary capacity of detoxifying heme even in nonhematophagous organisms. This latent function may represent a crucial pre-adaptive evolutionary step in the adoption of hematophagy in hemoparasites.
\end{abstract}

Keywords: Hemozoin, glycoside-hydrolases, heme biocrystallization.

\section{Introduction}

The glycosidases or glucoside hydrolases, comprise a group of enzymes that participate in the degradation of polysaccharides, in the biosynthesis and modification of cellular $\alpha$-glycoproteins, and in the catabolism of peptidoglycan and other glycoconjugates (Bhatia et al., 2001, Withers, 2010). These enzymes, which are present in mammals, plants, insects, and microorganisms, play important roles in cell signaling, during viral invasion, in energy storage and use, and in glycoprotein biosynthesis, among other functions (Zechel \& Withers, 2002). Among the glycosidases, $\alpha$ glucosidases (EC 3.2.1.20) catalyze the hydrolysis of the $\square-1,4$ glycoside linkage present in some oligo and polysaccharides, releasing $\square$-D-glucose monomers as their primary function (Zechel \& Withers, 2002).

Various groups of insects express $\alpha$-glucosidases in the digestive tract, where its activity is primarily associated with carbohydrate degradation (Terra \& Ferreira, 1994; Carneiro et al., 2004; Kubota et al., 2004; Damasceno-Sá et al., 2007; Zibaee et al., 2009; Santos et al., 2008; Fonseca et al., 2010; Ghadamyari, 2010; Vale et al., 2012; Watanabe et al.,
2013; Fialho et al., 2013; Mehrabadi, 2011; SouzaNeto et al., 2007). In aphids, $\alpha$-glucosidases control the osmolarity of sucrose diets (Ashford et al., 2000; Salvucci, 2000). The fact that these enzymes also act as receptors (Silva-Filha et al., 1999) suggests a high degree of functional plasticity. In Rhodnius prolixus, which is a blood sucking hemipteran, an $\alpha$ glucosidase present in perimicrovillar membranes may play a role in heme detoxification, participating in hemozoin (Hz) biosynthesis (Mury et al, 2009). Heme crystallization into $\mathrm{Hz}$ provides a defense against the oxidative effects of heme generated during the digestion of vertebrate hemoglobin in the intestinal lumen of this hematophagous insect. In other triatomine insects, $\alpha$-glucosidases also act in $\mathrm{Hz}$ biocrystallization (Oliveira et al., 2007) a preadaptive evolutionary step that enabled these animals to overcome the challenges of hematophagy (Mury et al, 2009).

The parasites Plasmodium (Slater et al., 1991), Schistossoma (Oliveira et al., 2000) and Hemoproteus (Chen et al., 2001) also produce Hz. In Plasmodium, the heme detoxification protein (HDP) participates in oxidative protection (Jani et al., 2008), but in Schistosoma, lipids take part in $\mathrm{Hz}$ formation

This article is published under the terms of the Creative Commons Attribution License 4.0

Author(s) retain the copyright of this article. Publication rights with Alkhaer Publications.

Published at: http://www.ijsciences.com/pub/issue/2015-08/

DOI: 10.18483/ijSci.791; Online ISSN: 2305-3925; Print ISSN: 2410-4477 
(Corrêa-Soares, et al., 2007; Hoang et al., 2010). In Plasmodium, $\mathrm{Hz}$ nucleation happens at the digestive vacuole inner membrane, with crystallization occurring in the aqueous rather than the lipid phase (Kapishnikova et al., 2012).

In this work, we tested the hypothesis that $\alpha$ glucosidases from organisms other than bloodsucking insects also form $\mathrm{Hz}$. Thus, we evaluated both activities in vitro using protein extracts from a variety of biological sources. The association between $\mathrm{Hz}$ forming and hydrolytic activities was tested by using inhibitors.

\section{Materials and Methods}

\subsection{Biological samples}

The midguts of the adult and larvae of Callosobruchus maculatus and Tribolium castaneum were kindly donated by Dr. Elenir Amâncio and Dr. Gustavo Rezende, respectively (LQFPP, CBB, UENF). The midgut Rhodnius prolixus females was used as a positive control (Silva et al., 2007). Midguts were washed in deionized water to remove luminal content and homogenized. The same procedure was applied to Dysdercus peruvianus and Quesada gigas.

The circulating adult form of Schistosoma mansoni, obtained through the courtesy of Dr. Marcus Fernandes de Oliveira (IBqM, UFRJ), was washed in deionized water and then centrifuged at $8000 \mathrm{x} g$ for 15 min at $4{ }^{\circ} \mathrm{C}$, after which the pellet was used in the protein extraction procedure described below. Arabidopsis thaliana leaves, kindly provided by Dr. Gonçalo Apolinário de Souza Filho (LBT, CBB, UENF), were macerated in liquid nitrogen and solubilized in distilled water. Log phase cells of Saccharomyces cerevisiae, courtesy of Dr. Lev Alexandrovitch Okorokov (LFBM, CBB, UENF), Bacillus thuringiensis, kindly provided by Dr. Marilia Amorim Berbert de Molina (LBT, CBB, UENF), Toxoplasma gondii, and Vero cells (ATCC® CCL$81^{\mathrm{TM}}$ ), both courtesy of Dr. Renato DaMatta (LBCT, $\mathrm{CBB}$, UENF) were harvested, washed in deionized water, and centrifuged at $8000 \mathrm{xg}$ for $15 \mathrm{~min}$ at $4{ }^{\circ} \mathrm{C}$.

\subsection{Protein Extraction}

Each sample was homogenized in distilled water using a Potter-Elvehjem glass homogenizer, followed by five cycles of freezing and unfreezing in liquid nitrogen. Between each cycle, samples were centrifuged at $15,000 \mathrm{xg}$ for $30 \mathrm{~min}$ at $4{ }^{\circ} \mathrm{C}$. Membrane-bound proteins were obtained by treatment of the pellet with $0.1 \%$ Nonidet P-40 (NP40) for $12 \mathrm{~h}$ at $4^{\circ} \mathrm{C}$ in $20 \mathrm{mM}$ sodium phosphate buffer, $\mathrm{pH}$ 7.4, $5 \mathrm{mM}$ imidazole, $1 \mathrm{mM}$ PMSF and 1 $\mathrm{mM}$ benzamidine (Silva et al., 2007). Samples were incubated overnight in the same buffer at $4{ }^{\circ} \mathrm{C}$ with agitation. After centrifugation at $15,000 \mathrm{x} g$ for 30 min at $4{ }^{\circ} \mathrm{C}$, protein concentration was determined by bicinchoninic acid (BCA) assay (Smith et al., 1985)

\subsection{Hemozoin formation assay}

A sample corresponding to $10 \mu \mathrm{g} / \mathrm{mL}$ of protein (protein extract) was incubated for $24 \mathrm{~h}$ at $28^{\circ} \mathrm{C}$ in $0.5 \mathrm{M}$ sodium acetate, $\mathrm{pH} 4.8$, in the presence of 100 $\mathrm{mM}$ heme as previously described (Sullivan et al., 1996). After incubation, the reaction mixture was centrifuged at $15,000 \mathrm{xg}$ for $15 \mathrm{~min}$ at $25{ }^{\circ} \mathrm{C}$. The pellet was washed three times with $1 \mathrm{~mL}$ of $0.1 \mathrm{M}$ $\mathrm{NaHCO} 3,2.5 \%$ SDS, pH 9.1, and twice with deionized water. The final pellet was solubilized in $0.1 \mathrm{M} \mathrm{NaOH}$, and the amount of heme was determined at $400 \mathrm{~nm}$ in a Shimadzu/UV-1240 spectrophotometer.

Alternatively, the specific $\alpha$-glucosidase inhibitors erythritol $(100 \mathrm{mM})$ and

diethylpyrocarbonate (DEPC) $(10 \mathrm{mM})$ or the specific hemozoin inhibitor chloroquine $(20 \mathrm{mM})$ were incubated with the sample and the amount of $\mathrm{Hz}$ formed was evaluated.

\section{$2.4 \alpha$-Glucosidase activity assay}

Enzyme activity was determined using $\square$-nitrophenyl $\alpha$-D-glucopyranoside (10 mM) (Sigma Aldrich Co., USA) in $100 \mathrm{mM}$ citrate phosphate buffer, $\mathrm{pH} 5.5$, as substrate and by following the formation of $\mathrm{p}$ nitrophenolate, according to the method of (Terra et al., 1979). All assays were performed at $37{ }^{\circ} \mathrm{C}$. Incubations were carried out for four different periods of time $(15,30,45$ and $60 \mathrm{~min})$. Reactions were stopped with $200 \mathrm{~mL}$ of $0.5 \mathrm{M} \mathrm{Na} 2 \mathrm{CO} 3$ and initial rates of hydrolysis were calculated. The absorbance of released $\square$-nitrophenolate was read at $405 \mathrm{~nm}$. Alternatively, erythritol $(100 \mathrm{mM})$, DEPC $(10 \mathrm{mM})$ or chloroquine $(20 \mathrm{mM})$, were incubated with the samples and $\alpha$-glucosidase activity was measured by the formation of $\rho$-nitrophenolate.

\subsection{Fourier transformed infrared (FTIR) spectroscopy}

To assess whether the heme pellet obtained as described above had the spectrum

characteristics of $\mathrm{Hz}$, samples were subjected to infrared spectroscopy (Slater et al., 1991) using Nicolet Magna 550 spectrometer.

\subsection{Statistical analysis}

Significant differences between groups were determined with the non-paired Student's $t$ test using the GraphPad Prism software. For all tests, a difference of $\mathrm{P}<0.05$ was considered to be significant.

\section{Results}

$3.1 \mathrm{~Hz}$-forming activity in epithelium protein extracts from Dysdercus peruvianus and Quesada gigas 
Our hypothesis that the $\alpha$-glucosidase from nonhematophagous insects forms $\mathrm{Hz}$ in vitro was tested using the luminal content of two non-hematophagous Hemiptera in $\mathrm{Hz}$ formation assays (Figure 1). Luminal content samples derived from D.peruvianus, a cotton seed bug (Figure 1A), and Q.gigas, the sapsucking cicada (Figure 1B), had pellets but not supernatants with biocrystallization activity. The FTIR spectra from both D.peruvianus and Q.gigas samples displayed peaks characteristic of $\mathrm{Hz}$ at 1207 and $1660 \mathrm{~cm}-1$, as previously described for R.prolixus (Oliveira et al., 1999) and for synthetic $\beta$ hematin (Chen et al., 2001). Thus, the perimicrovillar membranes from two non-hematophagous Hemiptera had a non-soluble fraction with $\mathrm{Hz}$-forming activity.

\section{2. $\alpha$-Glucosidase hydrolytic and Hz-forming activities in protein extracts from non-hemipteran insects}

The hydrolytic (Figure 2A) and Hz-forming (Figure 2B) activities of $\alpha$-glucosidase were measured in the soluble and non-soluble fractions of the midgut epithelia from two non-hemipteran insects, C.maculatus (larvae and adult) and T.castaneum (larvae and adult). R. prolixus material was used as a positive control. The non-soluble fractions of $C$. maculatus and $R$. prolixus displayed higher $\alpha$ glucosidase activity than their soluble fractions. T.castaneum samples had low activity, with no significant difference between the soluble and nonsoluble protein fractions. Hz-forming activity was substantially higher in non-soluble compared to soluble fractions (Figure 2B) and was higher in R.prolixus and T.castaneum than in C.maculatus larval midgut extracts.

3.3. $\alpha$-Glucosidase hydrolytic and Hz-forming activities in protein extracts from non-insects

Soluble and non-soluble protein fractions were also obtained from a group of non-insect organisms, including the yeast S.cerevisiae, the bacterium B.thuringiensis, the protozoan T.gondii, the platyhelminth S.mansoni, the plant A.thaliana, and cultured Vero cells. Both fractions were used in the assays of $\alpha$-glucosidase hydrolytic and Hz-forming activities (Figure 3A and 3B). Regarding hydrolytic activity, the only significant difference was the high level observed in the non-soluble protein fraction of S.mansoni in comparison to all other samples (Figure $3 \mathrm{~A})$. Hz-forming activity was significantly higher in the non-soluble fraction from all non-insect organisms (Figure 3B).

\section{4. $\alpha$-Glucosidase hydrolytic and Hz-forming} activities in protein extracts from insects in the presence and absence of inhibitors

We assessed the effects of chloroquine, an $\mathrm{Hz}$ synthesis inhibitor, and of DEPC and erythritol, both $\alpha$-glucosidase inhibitors, on $\alpha$-glucosidase hydrolytic and $\mathrm{Hz}$-forming activities in various insects and non- insects (Table 1). The activity of $\alpha$-glucosidase in C.maculatus and R.prolixus but not T.castaneum extracts was sensitive to erythritol. The same activity in extracts of C.maculatus larvae, T.castaneum larvae, and R.prolixus was significantly reduced in the presence of DEPC. Chloroquine reduced the hydrolytic activity of C.maculatus adult and R.prolixus extracts. The hydrolytic activity in S.cerevisae, S.mansoni, and Vero cell extracts was sensitive to erythritol and chloroquine and DEPC did not inhibit the hydrolytic activity of non-insect protein extracts except for that of S.mansoni extract. $\mathrm{Hz}$-forming activity was significantly reduced in the presence of erythritol, DEPC and chloroquine in all extracts from insect and non-insect organisms.

\section{Discussion}

In Triatomines insects, $\square$-glucosidase participates in $\mathrm{Hz}$ biocrystallization (Oliveira et al., 1999; Oliveira et al., 2007). This process occurs in the intestinal lumen, and probably represents a first line of defense against the oxidative effects of heme generated by digestion of vertebrate hemoglobin. Here, we show that midgut protein extracts from two nonhematophagous hemipteran insects, D.peruvianus and Q.gigas, also have Hz-forming activity (Figure 1). Our results suggest that $\mathrm{Hz}$ formation could be a secondary activity of other $\alpha$-glucosidases, and not a specific characteristic of these enzymes in hematophagous Hemiptera. To test this hypothesis further, we assessed the presence of this activity in other organisms. We chose two coleopteran insects, C.maculatus and T.castaneum. Larvae of both insects had higher $\alpha$-glucosidase hydrolytic activity than adults (Figure 2A). A residual $\mathrm{Hz}$ forming activity was found in these extracts if compared with the high activity of T.castaneum and R.prolixus extracts (Figure 2B).

We broadened the screening for $\mathrm{Hz}$ synthesis associated to $\alpha$-glucosidase to non-insect protein extracts. Among non-insects, high activity was found in the non-soluble protein extract from S.mansoni. All other extracts had low hydrolytic activity. However, Hz-forming activity was easily detectable in all extracts except in that from T.gondii, which had low activity only in the nonsoluble fraction of the extract.

While interesting, these results raise new questions. $\mathrm{Hz}$ activity could be related to other components of the protein extract such as the lipids present in the non-soluble fraction. (Stiebler et al., 2011). reviewed the factors involved in $\mathrm{Hz}$ synthesis in diverse biological systems. In R.prolixus midgut, both lipid and protein factors from PMM cooperate to promote $\mathrm{Hz}$ synthesis (Stiebler et al., 2010). In S.mansoni, Hz is also produced physiologically, and lipids seem to be the main agents of $\mathrm{Hz}$ formation (Corrêa-Soares et al., 2007). In P.falciparum, a heme detoxification 
protein (HDP) as well as lipids were implicated in $\mathrm{Hz}$ synthesis (Jani et al., 2008; Fitch et al., 1999) Faced with these possibilities, we tested the effects of inhibitors of $\alpha$-glucosidase hydrolytic activity on $\mathrm{Hz}$ synthesis. We also tested the effects of a known inhibitor of $\mathrm{Hz}$ synthesis on the hydrolytic activity of $\alpha$-glucosidase.

DEPC inhibits several enzymes by modifying histidine residues (Coan \& DiCarlo, 1990) or by linking the $\varepsilon$-amino group in lysine residues to the carboxyl groups of glutamic and aspartic acid residues (Wolf et al., 1970).

DEPC treatment inhibits the activity of C.elegans $\alpha$ glucosidase by $40 \%$ (Torre-Bouscoulet et al., 2005). Erythritol is a competitive inhibitor of $\alpha$-glucosidases (Ridleyet al., 1992). Both inhibitors were used here to assess the presence of $\alpha$-glucosidase activity in association with $\mathrm{Hz}$ synthesis in the extracts (Table 1). The results show that not all extracts showed $\square$ glucosidase activities sensitive to the inhibitors. Quinoline drugs, such as chloroquine, act against Plasmodium through $\mathrm{Hz}$ synthesis inhibition (Sullivan et al., 1996; Oliveira et al, 1999; Ridley et al., 1997). These drugs inhibit $\mathrm{Hz}$ synthesis in vitro and under physiological conditions (Slater \& Cerami, 1992). The action of these antimalarial drugs in S.mansoni (Corrêa-Soares et al., 2009), through an identical mechanism, opens a new front of chemotherapy development.

Here, chloroquine inhibited the Hz-forming activity of all protein extracts (Table 1). On the other hand, chloroquine also reduced hydrolytic activity in C.maculates, R.prolixus, S.cerevisae, S.mansoni and Vero cells. Unexpectedly, the $\alpha$-glucosidase inhibitors were also able to decrease $\mathrm{Hz}$ forming activity in almost all protein extracts except Vero Cell extract. These results suggest a potential physical association of both activities within the enzyme structure. Moreover, our findings indicate that chloroquine and the other inhibitors can be used to assess both $\alpha$-glucosidase hydrolytic and $\mathrm{Hz}$ forming activities.

Our group has shown that $\alpha$-glucosidase present in the PMM of R.prolixus may be related to the process of heme detoxification and $\mathrm{Hz}$ synthesis (Mury et al., 1999). Heme molecules interact with PMM, binding to them in regular intervals, which would facilitate the formation of crystals. Interaction with PMM is mediated by $\alpha$-glucosidase located in these membranes (Ferreira et al., 1988; Smith et al., 2004). During the formation of heme crystal, the nucleation process is a limiting step. $\alpha$-Glucosidases would promote the nucleation process and $\mathrm{Hz}$ formation at the interface between PMM and the intestinal lumen (Mury et al., 1999; Stiebler et al., 2011). Once Hz crystals are formed in the PMM in the early stages of the digestive process, further heme crystallization becomes physiologically very effective. This increased effectiveness certainly explains why $97 \%$ of the heme in the midgut of R.prolixus is found in the form of $\mathrm{Hz}$ (Stiebler et al., 2010).

We presented an initial hypothesis that $\square$ glucosidases from organisms other than bloodsucking insects would have, as a secondary activity, the capacity to crystallize heme. Indeed, we showed here that protein extracts derived from nonhematophagous insects such as C.maculatus and T.castaneum as well as those from non-insects, including S.mansoni, A.thaliana, T.gondii, and S.cerevisae, exhibited heme biocrystallization activity. Furthermore, this activity was likely associated with $\square$-glucosidases. This catalytic potential provides further evidence of the plasticity of $\square$-glucosidases, and may represent a crucial preadaptive evolutionary step in the adoption of hematophagy in hemoparasites.

Acknowledgments

We thank Isabela Sampaio and Cristóvão Pinheiro for their technical assistance.

This work was supported by FAPERJ and INCTEM, Brazil.

This manuscript was reviewed by a professional science editor and by a native English-speaking copy editor to improve readability.

\section{References}

1. Ashford DA, Smith WA, Douglas AE (2000). Living on a high sugar diet: the fate of sucrose ingested by a phloemfeeding insect, the pea aphid Acyrthosiphon pisum, J. Insect Physiol. 46:335-341. http://dx.doi.org/10.1016/s00221910(99)00186-9

2. Auricchio F, Bruni CB, Sica V (1968). Further purification and characterization of the acid alphaglucosidase, Biochem. J. 108:161-7. http://dx.doi.org/10.1042/bj1080161

3. Bhatia Y, Mishra S, Bisaria VS (2002). Microbial $\beta$ glucosidases: Cloning, properties and applications, Crit.Rev.Biotechnol. 22: 375-407.

http://dx.doi.org/10.1080/07388550290789568

4. Chen MM, Shi L, Sullivan JRDJ (2001). Haemoproteus and Schistosoma synthesize haem polymers similar to Plasmodium hemozoin and betahematin. Mol. Biochem. Parasitol. 113:1-8. http://dx.doi.org/10.1016/s01666851(00)00365-0

5. Coan C, DiCarlo R (1990). Effect of diethyl pyrocarbonate modification on the calcium binding mechanism of the sarcoplasmic reticulum ATPase, J. Biol. Chem. 265: 537684.

6. Corrêa-Soares JB, Menezes D, Vannier-Santos MA, Ferreira-Pereira A, Almeida GT, Venancio TM, VerjovskiAlmeida S, Zishiri VK, Kuter D, Hunter R, Egan TJ, Oliveira MF (2009). Interference with hemozoin formation represents an important mechanism of schistosomicidal action of antimalarial quinoline methanols, PLoS Negl. Trop. Dis. 3:e477. http://dx.doi.org/10.1371/journal.pntd.0000477

7. Corrêa-Soares JB, Maya-Monteiro CM, Bittencourt-Cunha PR, Atella GC, Lara FA, d'Avila JC, Menezes D, VannierSantos MA, Oliveira PL, Egan TJ, Oliveira MF (2007). Extracellular lipid droplets promote hemozoin crystallization in the gut of the blood fluke Schistosoma mansoni, FEBS Lett. http://dx.doi.org/10.1016/j.febslet.2007.03.054 
8. Damasceno-Sa JC, Carneiro CNB, Damatta RA, Samuels RI, Terra WR, Silva CP (2007). Biphasic perimicrovillar membrane production following feeding by previously starved Dysdercus peruvianus (Hemiptera: Pyrrhocoridae), J.Insect Physiol. 53:592-600. http://dx.doi.org/10.1016/j.jinsphys.2007.02.017

9. Ferreira C, Ribeiro AF, Garcia ES \& Terra WR (1988). Digestive enzymes trapped between and associated with the doublé plasma membranes of Rhodnius prolixus posterior midgut cells, Insect Biochem. Mol. Biol. 18:521-530. http://dx.doi.org/10.1016/j.jinsphys.2007.02.017

10. Fialho MCQ, Terra WR, Moreira NR, Zanuncio JC, Serrão JE (2013). Ultrastructure and immunolocalization of digestive enzymes in the midgut of Podisus nigrispinus (Heteroptera: Pentatomidae), Arthropod Struct. Dev. 42:277 - 285. http://dx.doi.org/10.1016/j.asd.2013.03.002

11. Fitch CD, Cai GZ, Chen YF, Shoemaker JD (1999). Involvement of lipids in ferriprotoporphyrin IX polymerization in malaria, Biochim. Biophys. Acta 1454: 3137. http://dx.doi.org/10.1016/s0925-4439(99)00017-4

12. Fonseca FV, Silva JR, Samuels RI, DaMatta RA, Terra WR, Silva CP (2010). Purification and partial characterization of a midgut membrane-bound $\alpha$-glucosidase from Quesada gigas (Hemiptera: Cicadidae), Comp. Biochem. Physiol. 155B: 2025. http://dx.doi.org/10.1016/j.cbpb.2009.09.004

13. Ghadamyari M, Hosseininaveh V, Sharifi M (2010). Partial biochemical characterization of $\alpha$ - and $\beta$-glucosidases of lesser mulberry pyralid, Glyphodes pyloalis Walker (Lep.: Pyralidae), C. R. Biol. 333: 197-204. http://dx.doi.org/10.1016/j.crvi.2009.12.011

14. Hoang AN, Ncokazi KK, de Villiers KA, Wright DW, Egan TJ (2010). Crystallization of synthetic haemozoin ( $\beta$ haematin) nucleated at the surface of lipid particles, Dalton T. 39: 1235-1244. http://dx.doi.org/10.1039/b914359a

15. Jani D, Nagarkatti R, Beatty W, Angel R, Slebodnick C, Andersen J, Kumar S, Rathore D (2008). HDP - a novel heme detoxification protein from the malaria parasite, PLoS Pathog. 4: e1000053. http://dx.doi.org/10.1371/journal.ppat.1000053

16. Kapishnikova S, Weinera A, Shimonib E, Guttmannc P, Schneiderc G, Dahan-Pasternakd N, Dzikowskid R, Leiserowitza L, Elbauma M (2012). Oriented nucleation of hemozoin at the digestive vacuole membrane in Plasmodium falciparum, P. Natl. Acad. Sci. USA 109: 11188-11193.

17. Kubota M, Tsuji M, Nishimoto M, Wongchawalit J, Okuyama M, Mori H, Matsui H, Surarit R, Svsti J, Kimura A, Chiba S (2004). Localization of $\alpha$-Glucosidases I, II and III in Organs of European 398 Honeybees, Apis mellifera L., and the Origin of $\alpha$-Glucosidase in Honey, Biosci. Biotech. Bioch. 68: 2346-2352. http://dx.doi.org/10.1271/bbb.68.2346

18. Mehrabadi M, Bandani AR. Secretion and Formation of Perimicrovillar Membrane in the Digestive System of the Sunn Pest, Eurygaster integriceps (Hemiptera: Scutelleridae) in Response to Feeding, Arch.Insect Biochem. 78 (2011) 190-200. http://dx.doi.org/10.1002/arch.20452

19. Mury FB, Silva, JR, Ferreira LS, Ferreira BS, Souza-Filho GA, Souza-Neto JA, Ribolla PEM, Silva CP, Nascimento VV, Machado OLT, Berbert-Molina MA, DansaPetretski M (2009). Alpha-glucosidase forms hemozoin in a bloodsucking bug: an evolutionary history, PLoS ONE. 4: e6966. http://dx.doi.org/10.1371/journal.pone.0006966

20. Oliveira MF, Gandara AC, Braga CM, Silva JR, Mury FB, Dansa-Petretski M, Menezes D, Vannier-Santos MA, Oliveira PL (2007). Heme crystallization in the midgut of triatomine insects, Comp. Biochem. Physiol. Part C: Toxicol. Pharmac.

http://dx.doi.org/10.1016/j.cbpc.2006.12.007

146:168-74.

21. Oliveira MF, Gandara AC, Braga CM, Silva JR, Mury JB, Dansa-Petretski M, Menezes D, Vannier-Santos MA, Oliveira PL (2007). Heme crystallization in the midgut of triatomine insects, Comp. Biochem. Physiol. Part C: Toxicol. Pharmacol. 146 :

$168-74$. http://dx.doi.org/10.1016/j.cbpc.2006.12.007

22. Oliveira MF, d' Avila JC, Torres CR, Oliveira PL, Tempone AJ, Rumjanek FD, Braga CM, Silva JR, Dansa-Petretski M,
Oliveira MA, de Souza W, Ferreira ST (2000). Haemozoin in Schistosoma mansoni. Mol. Biochem. Parasitol. 111: 217 221. http://dx.doi.org/10.1016/s0166-6851(00)00299-1

23. Oliveira MF, Silva JR, Dansa-Petretski M, de Souza W, Lins U, Braga CMS, Masuda H, Oliveira PL (1999). Haem detoxification by an insect, Nature, 400: 517-518. http://dx.doi.org/10.1038/22910

24. Ridley DG, Dorn A, Vippagunta SR, Vennerstrom JL (1997). Haematin (haem) polymerization and its inhibition by chloroquine antimalarials, Ann. Trop. Med. Parasitol. 91 559-566.

25. Salvucci ME (2000). Effect of the alpha-glucosidase inhibitor, bromoconduritol, on carbohydrate metabolism in the silverleaf whitefly, Bemisia argentifolii, Arch. Insect Biochem. 45 (2000) 117-28. http://dx.doi.org/10.1002/15206327(200011)45:3\%3C117::aid-arch3\%3E3.0.co;2-t

26. Silva-Filha MH, Nielsen-LeRoux C, Jean-François C (1999). Identification of the receptor for Bacillus sphaericus crystal toxin in the brush border membrane of the mosquito Culex pipiens (Diptera: Culicidae), Insect Biochem. Mol. Biol. 29 711-721. http://dx.doi.org/10.1016/s0965-1748(99)00047-8

27. Silva JR, Mury FB, Oliveira MF, Oliveira PL, Silva CP, Dansa-Petretski M (2007). Perimicrovillar membranes promote hemozoin formation into Rhodnius prolixus midgut, Insect Biochem. Mol. Biol. 37: 523-531 http://dx.doi.org/10.1016/j.ibmb.2007.01.001

28. Silva CP, Ribeiro AF, Gulbenkian S \& Terra WR (1995). Organization, origin and function of the outer microvilar (perimicrovilar) membranes of Dysdercus peruvianus (Hemiptera) midgut cells, J. Insect. Physiol. 41: 1093-1103. http://dx.doi.org/10.1016/0022-1910(95)00066-4

29. Slater AF, Cerami A (1992). Inhibition by choroquine of a novel haem polymerase enzyme and activity in malaria trophozoites. $\quad$ Nature, 355 : 167-169. http://dx.doi.org/10.1038/355167a0

30. Slater AFG, Swiggard WJ, Orton BR, Flitter WD, Goldberg E, Cerami A \& Henderson GB (1991). An ironcarboxylate bond links the heme units of malaria pigment, $\mathrm{P}$. Natl. Acad. Sci. USA 88: 325-329. http://dx.doi.org/10.1073/pnas.88.2.325

31. Smith JD, Tang BC, Robinson AS (2004). Protein disulfide isomerase, but not binding protein, overexpression enhances secretion of a non-disulfide-bonded protein in yeast, Biotechnol. Bioeng. $\quad 85: \quad 340-50$ http://dx.doi.org/10.1002/bit.10853

32. Smith PR, Krohn RI, Hermanson GT, Mallia AK, Gartner FH, Provezano MD, Fujimoto EK, Goeke NM, Olson BJ Klenk DC (1985). Measurements of protein using bicinchonicacid, Anal. Biochem. 150: 76-85.

33. Souza-Neto JA, Machado FP, Lima JB, Valle D, Ribolla PEM (2007). Sugar digestion in mosquitoes: Identification and characterization of three midgut $\alpha$-glucosidases of the neotropical malaria vector Anopheles aquasalis (Diptera:Culicidae), Comp. Biochem. Physiol. 147: 993 1000. http://dx.doi.org/10.1016/j.cbpa.2007.03.008

34. Stiebler R, Soares JBR, Timm BL, Silva JR, Mury FB, Dansa-Petretski M, Oliveira MF (2011). On the mechanisms involved in biological heme crystallization, J.Bioenerg. Biomemb. 43: 93-99. http://dx.doi.org/10.1007/s10863-0119335-x

35. Stiebler R, Timm BL, Oliveira PL, Hearne GR, Egan TJ, Oliveira MF (2010). On the physicochemical requeriments of hemozoin formation promoted by the perimicrovillar membranes in Rhodnius prolixus midgut, Insect Biochem. Mol. Biol. 40 : 284-292. http://dx.doi.org/10.1016/j.ibmb.2009.12.013

36. Sullivan JRDJ, Gluzman IY \& Goldberg DE (1996) Haemozoin formation mediated by histidine-rich proteins, Science 271: 219-221. http://dx.doi.org/10.1126/science.271.5246.219

37. Terra WR, Ferreira C (1994). Insect digestive enzymes: properties, compartmentalization and function, Comp. Biochem. Physiol. 109B: 1-62.

38. Terra WR, Terra IC, Ferreira C, de Bianchi AG (1979) Carbodiimide-reactive carboxyl groups at the active site of an 
insect midgut trehalase, Biochim. Biophys. Acta 571: 79-85. http://dx.doi.org/10.1016/0005-2744(79)90227-4

39. Torre-Bouscoulet ME, López-Romero E, Balcázar-Orozco R, Calvo-Méndez C, Flores-Carreón A (2005). Partial purification and biochemical characterization of a soluble alpha-glucosidase Illike activity from Candida albicans, FEMS Microbiol. Lett. 251: 355. http://dx.doi.org/10.1016/j.femsle.2004.05.033

40. Vale VF, Moreira BH, Pereira MH, Genta FA, Gontijo NF (2012). Carbohydrate digestion in Lutzomyia longipalpis' larvae (Diptera - Psychodidae), J. Insect Physiol. 58: 314-24. http://dx.doi.org/10.1016/j.jinsphys.2012.07.005

41. Watanabe S, Kakudo A, Ohta M, Mita K, Fujiyama K, Inumaru S (2013). Molecular cloning and characterization of the $\alpha$-glucosidase II from Bombyx mori and Spodoptera frugiperda, Insect Biochem. Mol. Biol. 43: 319- 327. http://dx.doi.org/10.1016/j.ibmb.2013.01.005
42. Withers $N$ (2010). Liesegang rings: nanoparticles ring the $\begin{array}{llll}\text { changes, } & \text { Nat. } & \text { Chem. } & 2 \text { : } \\ \end{array}$ http://dx.doi.org/10.1038/nchem.568

43. Wolf B, Michelin-Lausarot P, Lesnaw JA, Reichmann ME (1970). Preparation of polymeric protein markers and an investigation of their behavior in sodium dodecyl sulfatepolyacrylamide gel electrophoresis, Biochim. Biophys. Acta 200: $180 . \quad$ http://dx.doi.org/10.1016/0005 2795(70)90060-7

44. Zechel DL \& Withers SG (2000). Glycosidase Mechanisms: Anatomy of a Finely Tuned Catalyst, Accounts Chem Res. 33: 11-18. http://dx.doi.org/10.1002/chin.200015237

45. Zibaee A, Bandani AR, Ramzi S (2009). Enzymatic properties of $\alpha$ - and $\beta$ - glocusidases extracted from midgut and salivary glands of rice striped stem borer, Chilo suppressalis Walker (Lepidoptera: Pyralidae), C. R. Biol 332: 633-641. http://dx.doi.org/10.1016/j.crvi.2009.02.009

Legends

Table 1: In vitro assessment of $\alpha$-glucosidase and $\mathrm{Hz}$ forming activities in the non-soluble fraction of protein extracts from insects and non-insects, in the presence or absence of inhibitors erythritol, DEPC and chloroquine.

Figure 1: Hemozoin synthesis in the protein extract from the epithelia of D.peruvianus (A) and Q.gigas (B). The intestinal epithelium samples were collected and subjected to protein extraction. The hemozoin synthesis assay was performed using $12 \mu \mathrm{g}$ of protein supernatant $(\mathrm{S})$ or pellet $(\mathrm{P})$. Insets show the insects used and the FTIR spectra of the crystals produced in vitro.

Figure 2: $\alpha$-Glucosidase activity (A) and hemozoin formation (B) in soluble (S) and nonsoluble (NS) fractions of protein extracts from different insects. C - Control; Cm.L - C.maculatus Larva; Cm.A. - C.maculatus Adult; Rpro - R.prolixus Adult. Tc L. - T.castaneum Larva; Tc A - T.castaneum Adult. Hemozoin formation assays were carried out for $24 \mathrm{~h}$ at $28 \mathrm{oC}$. Hemozoin formation activity is expressed as nmol heme aggregated in $24 \mathrm{~h}$ for $12 \mu \mathrm{g}$ of protein extract. $\alpha$-Glucosidase activity is expressed as nmol $\rho$-nitrofenolate released in 1 min. Results shown are means \pm SEM $(\mathrm{n}=4)$ of three experiments run in triplicate. $*(p<0 . .05) ; * * *(p<0.001)$.

Figure 3: $\alpha$-Glucosidase activity (A) and hemozoin formation (B) in soluble (S) and nonsoluble (NS) fractions of protein extracts from different non-insect organisms. C - Control; Yeast - S.cerevisiae.. Bt - B.thuringiensis; Schist. - S.mansoni. Vero - Vero Cells; Ara - A.thaliana. Toxo - T.ghondii. Hemozoin formation assays were carried out for $24 \mathrm{~h}$ at $28^{\circ} \mathrm{C}$. Hemozoin formation activity is expressed as nmol heme aggregated in $24 \mathrm{~h}$ for $12 \mu \mathrm{g}$ of protein extract. $\alpha$-Glucosidase activity is expressed as nmol $\rho$-nitrofenolate released in 1 min. Results shown are means \pm SEM $(\mathrm{n}=4)$ of three experiments run in triplicate. $* * *(p<0.001)$. 
Table 1

\begin{tabular}{|c|c|c|c|c|c|c|c|}
\hline \multirow[t]{2}{*}{ Sample } & \multicolumn{7}{|c|}{ Insect extracts - $\alpha$-Glucosidase activity $(\mathrm{mU} / \mathrm{mg})$} \\
\hline & Control & Ervthritol & $\rho$-value & + & $\rho$-value & +Chloroquine & $\rho$-value \\
\hline C. maculatus & 1047.03 & 112.5 & $0.0232 *$ & 600.18 & $0.036 *$ & 900.18 & 0.4228 \\
\hline C. maculatus adult & 89.40 & 23.52 & $0.0128^{*}$ & 154.58 & 0.2691 & 115.58 & $0.031^{*}$ \\
\hline R. prolixus adult & 287.04 & 26.465 & $0.0007 * * *$ & 104.96 & $0.0017^{*} *$ & 89.69 & $0.0031 * *$ \\
\hline T. castaneum & 101.17 & 105.40 & 0.7456 & 50.77 & $0.001^{* *}$ & 90.81 & 0.1461 \\
\hline T. castaneum & 41.99 & 82.76 & 0.0503 & 30.15 & 0.4587 & 70.23 & 0.0544 \\
\hline \multirow[t]{2}{*}{ Sample } & \multicolumn{7}{|c|}{ Non-insect extracts - $\alpha$-Glucosidase activity $(\mathrm{mU} / \mathrm{mg})$} \\
\hline & Control & Ervthritol & $\rho$-value & DEPC & $\rho$-value & Chloroquine & $\rho$-value \\
\hline S. cerevisae & 93.35 & 28.94 & $0.0148 *$ & 103.76 & 0.1565 & 47.73 & $0.0142 *$ \\
\hline B. thuringiensis & 62.64 & 12.88 & 0.0549 & 47.9 & 0.3083 & 46.23 & 0.3194 \\
\hline S. mansoni & 380.86 & 37.93 & $0.0005^{\text {*a*k }}$ & 199.99 & $0.0025^{* * *}$ & 198.99 & $0.0042 * *$ \\
\hline Vero Cells & 72.93 & 17.17 & $0.0048^{* * *}$ & 78.8 & 0.1907 & 42.34 & $0.0171^{*}$ \\
\hline T. gondii & 43.05 & 40.93 & 0.623 & 39.25 & 0.1476 & 26.84 & 0.1099 \\
\hline A.thaliana & 126.17 & 27.93 & 0.1257 & 77.05 & 0.3283 & 61.76 & 0.2375 \\
\hline \multirow[t]{2}{*}{ Sample } & \multicolumn{7}{|c|}{ Insect extracts - $\mathrm{Hz}$ forming activity } \\
\hline & Control & Ervthritol & $\rho$-value & DEPC & $\rho$-value & Chloroquine & $\rho$-value \\
\hline C. maculatus & 0.21 & 0.13 & $0.0002^{* * * *}$ & 0.09 & $0.0001 * * *$ & 0.03 & 0.0001 *** \\
\hline C. maculatus adult & 6.52 & 0.23 & $0.0001^{\text {*2*k }}$ * & 1.70 & $0.0003^{*}$ *** & 0.06 & $0.0001^{*} * * *$ \\
\hline R. prolixus adult & 9.98 & 0.17 & $0.0001^{\text {*a*k }}$ & 1.16 & $0.0001^{* * * *}$ & 0.02 & $0.0001^{* * * *}$ \\
\hline T. castaneum & 0.32 & 1.18 & $0.0001^{\text {*ak }}$ * & 0.32 & $0.0001^{*} * *$ & 0.03 & $0.0001^{*}$ *** \\
\hline T. castaneum & 1.22 & 1.32 & $0.0013 * *$ & 1.22 & $0.0024 * *$ & 0.03 & $0.0001^{* * * *}$ \\
\hline Control & 0.03 & 0.03 & & 0.03 & & 0.03 & \\
\hline \multirow[t]{2}{*}{ Sample } & \multicolumn{7}{|c|}{ Non-insect extracts - $\mathrm{Hz}$ forming activity } \\
\hline & Control & Ervthritol & $\rho$-value & DEPC & $\rho$-value & Chloroquine & $\rho$-value \\
\hline S. cerevisae & 1.14 & 0.27 & $0.0001^{\text {*ak }}$ * & 2.03 & $0.0001^{*} * *$ & 0.04 & $0.0001^{*}$ *** \\
\hline B. thuringiensis & 9.98 & 0.17 & $0.0001^{\text {***k }}$ & 1.16 & $0.0003^{* * * *}$ & 0.02 & $0.0001^{* * * *}$ \\
\hline S. mansoni & 5.97 & 1.51 & $0.0001^{\text {*ak }}$ * & 3.20 & $0.0001^{*}$ *** & 0.05 & $0.0001^{*}$ *** \\
\hline Vero Cells & 7.27 & 4.14 & $0.0029 * *$ & 8.20 & 0.1578 & 0.05 & $0.0001^{\text {**** }}$ \\
\hline T. gondii & 2.81 & 1.47 & $0.0001^{\text {*a*k }}$ & 2.81 & $0.0001^{* * * *}$ & 0.04 & $0.0001^{* * * * *}$ \\
\hline A.thaliana & 3.36 & 0.40 & 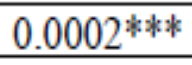 & 2.88 & $0.0001^{* * * *}$ & 0.05 & \\
\hline Control & 0.03 & 0.03 & & 0.03 & & 0.03 & \\
\hline
\end{tabular}

DEPC - diethylpyrocarbonate. One mU of $\alpha$-Glucosidase activity is defined as one nMol of $\rho$-nitrofenolate released per min. Results shown means $\pm \operatorname{SEM}(\mathrm{n}=4)$ of two experiments run in triplicate. $*(p<0.05) ; * *(p<0.01)$. $* * *(p<0.001)$.

$\mathrm{Hz}$ forming assays were carried out for $24 \mathrm{~h}$ at $28^{\circ} \mathrm{C}$. Hz formation activity is expressed as nmol heme in $24 \mathrm{~h}$ for $12 \mu \mathrm{g}$ protein extract. Resu shown are means $\pm \operatorname{SEM}(\mathrm{n}=4)$ of two experiments run in triplicate. $*(p<0.05) ; *(p<0.01)$. *** $(p<0.001)$. 
Figure 1
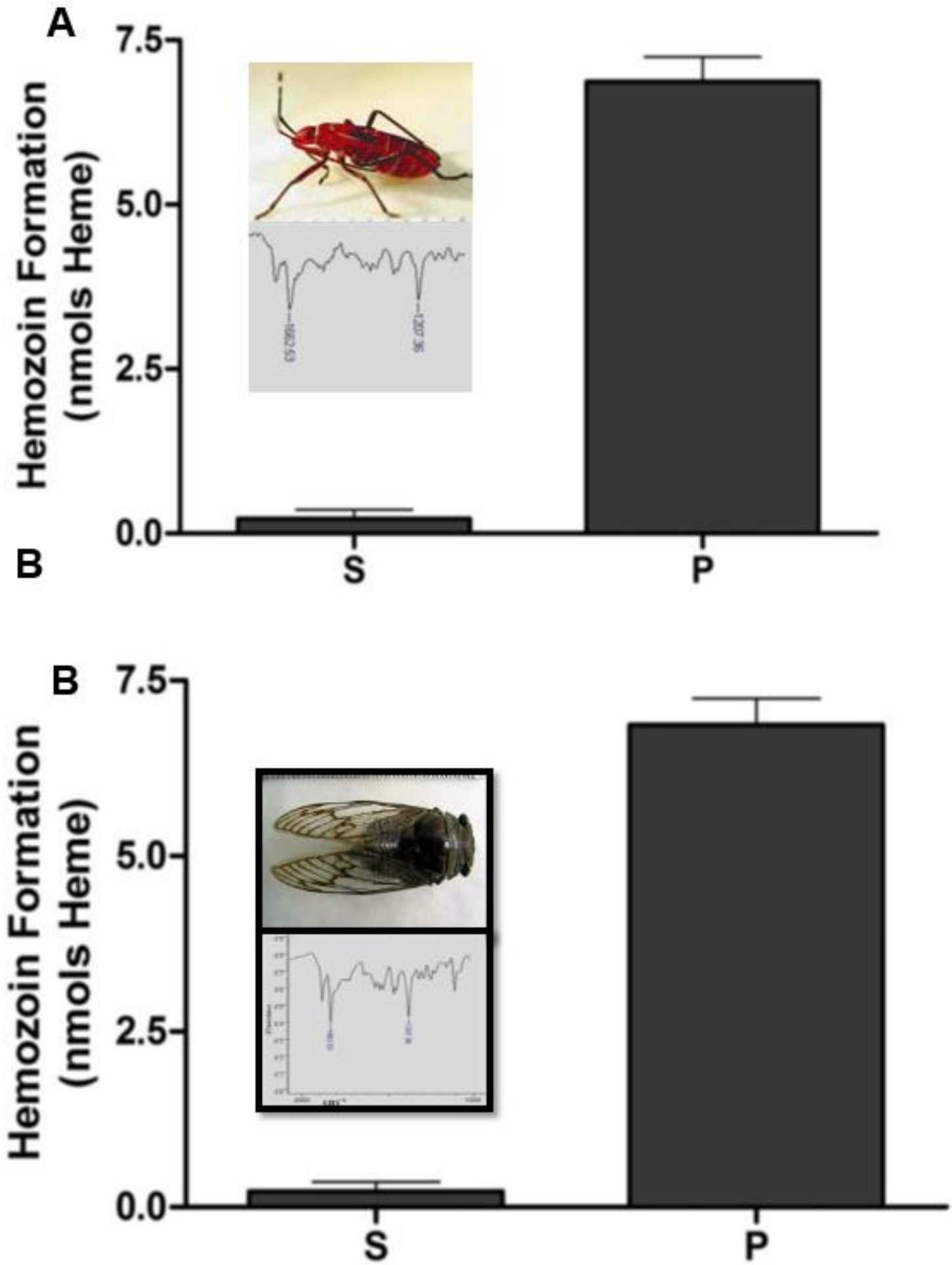
Figure 2
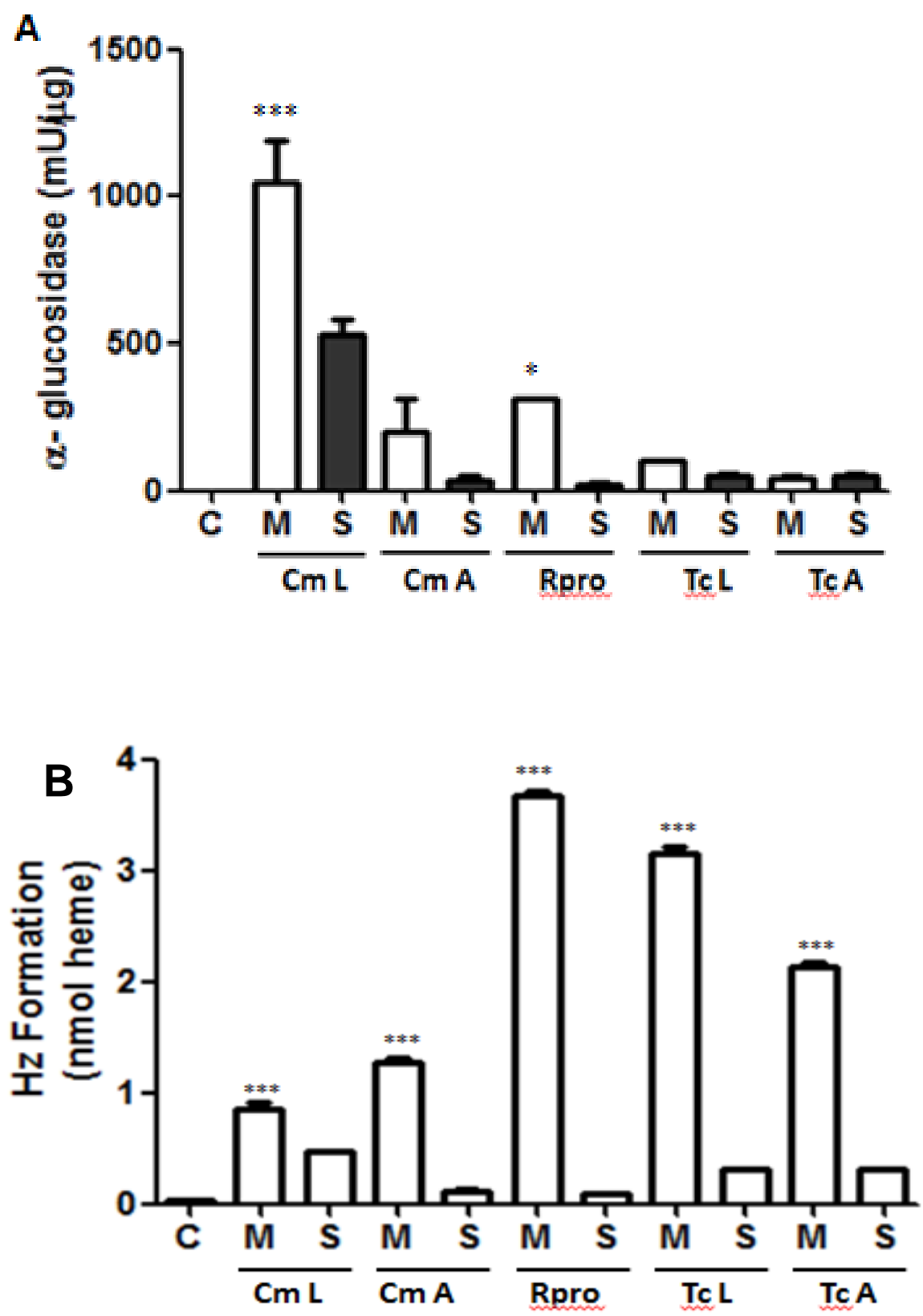
Figure 3
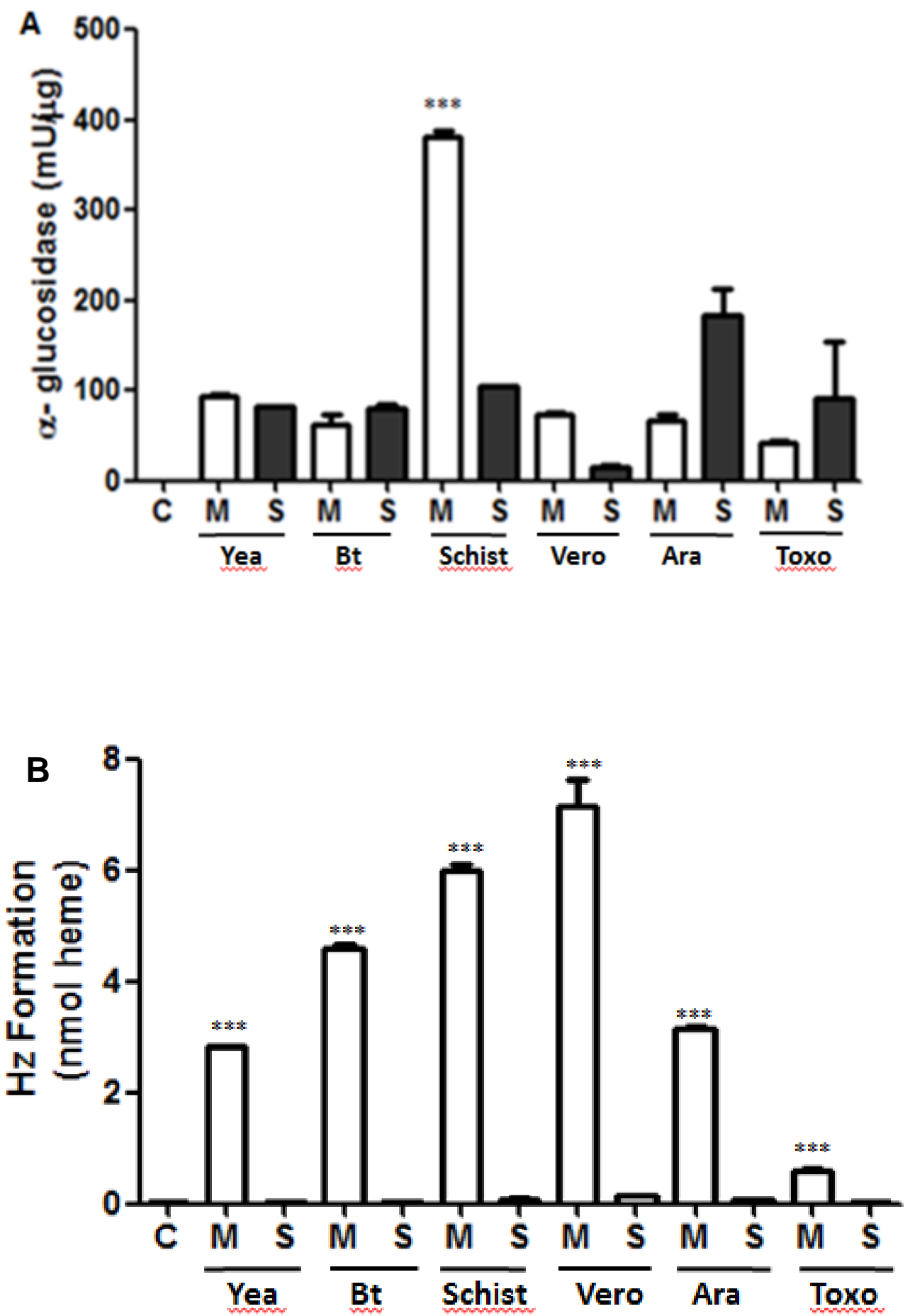